\title{
Tariff Integration for Public Transportation in the Metropolitan Area of Bucaramanga*
}

\section{Integración Tarifaria para el Transporte Público del Área Metropolitana de Bucaramanga}

\author{
DOI: http://dx.doi.org/10.17981/ingecuc.11.1.2015.02
}

Case Study - Reception Date: July 15, 2014 - Acceptance Date: March 13, 2015

José Carlos Jiménez Serpa

Master in Civil Engineering, Universidad Pontificia Bolivariana. Bucaramanga (Colombia). jose.jimenez@upb.edu.co

\author{
Andrés Eduardo Rojas Sánchez \\ Master in Civil Engineering, Universidad Pontificia Bolivariana. Bucaramanga (Colombia). andres.rojass.2014@upb.edu.co \\ Miller Humberto Salas Rondón \\ Doctor of Civil Engineering, Universidad Pontificia Bolivariana. Bucaramanga (Colombia). miller.salas@upb.edu.co
}

To cite this paper:

J. C. Jiménez Serpa, A. E. Rojas Sánchez and M. H. Salas Rondón, "Tariff Integration for Public Transportation in the Metropolitan Area of Bucaramanga," INGE CUC, vol. 11, no. 1, pp. 25-33, 2015. DOI: http://dx.doi.org/10.17981/ingecuc.11.1.2015.02

\begin{abstract}
The sole implementation of a Bus Rapid Transit System -BRT parallel to the conventional is not enough to guarantee meeting users and operators' needs within the Metropolitan Area of Bucaramanga -MAB, Colombia. As time passed, these systems became inefficient; as a result, users started looking for alternative non-formal transportation means and the State incurred in additional financing for the permanence of the system. This paper seeks to bolster the modes of public transportation through a fare strategy that agrees with the actual distances travelled by the user. In other words, the purpose of this work is to establish tariff zones for the AMB to differentiate between those users moving in short journeys and those who travel long distances to get to their destination in order to create a balance between the users' benefit, the quality of the travel, and the operation costs of BRT.
\end{abstract}

Keywords - Bus Rapid Transit -BRT, Tariff Integration, Accessibility, Quality of Service, Mass Transportation System.
Resumen - La implementación de un sistema de transporte público masivo paralelo al convencional no es garantía suficiente para satisfacer las necesidades de los usuarios y de los operadores dentro del Área Metropolitana de Bucaramanga -AMB-, los cuales a través del tiempo se van tornando ineficientes y conllevan a que los usuarios busquen alternativas de transporte no formales y el Estado incurra en financiamientos adicionales para la permanencia del sistema. Con este artículo se propone fortalecer los modos de trasporte público mediante una estrategia tarifaria que se ajuste a las distancias recorridas por el usuario. Es decir, establecer unas zonas o coronas tarifarias para el AMB que permitan diferenciar entre aquellos usuarios que se mueven en trayectos cortos y otros que recorren grandes distancias para llegar a su destino, generando así balance entre el bienestar de los usuarios, la calidad del viaje y los costos de operación del sistema de transporte público.

Palabras claves - Transporte público, Integración tarifaria, Accesibilidad, Calidad del servicio, Sistema masivo.

\footnotetext{
"Research paper deriving from the research Project "Planteamiento de criterios para viabilizar el cobro por cogestión de vías saturadas en Bucaramanga". Funded by Universidad Pontificia Bolivariana. Starting date: February 2014. Ending date: July 2015.
} 


\section{INTRODUCTION}

The lack of fare alternatives and cash use in the current transportation system has proven ineffective and, on the contrary, provides an adverse and uncomfortable effect on the user. This paper sets forth a proposal to modify the current fare system in the Metropolitan Area of Bucaramanga MAB regarding urban public transportation -buses and vans- so as to make this system more attractive for users. On the one hand, the proposal entails the elimination of cash use when boarding the public transportation vehicle through the use of smart cards [1] or bank transferences using smartphones [2]. On the other hand, broadening the fare offer for the service, this means, the creation of different 'travel packages': daily, weekly, or monthly packages; besides this, offering special fare discounts for certain social groups, for example students or elderly people.

Today, bus drivers from the conventional system do not earn a fixed salary, they receive a commission for every passenger, which is $\$ 100$ COP approximately, this is $\approx \mathrm{US} \$ 0.04$-for the purpose of this work, $\mathrm{US} \$ 1$ is equivalent to $\$ 2,400 \mathrm{COP}$ in February, 2015. This circumstance generates conflicts as the "cent war" [3], which continue to be one of the most deteriorating factors when providing the service since bus drivers fight over users. Additionally, it has affected allocative efficiency as there is no system offering price-level combinations for the service in order to value not only the operator's cost, but also the user's by considering the amount of time spent travelling [4] since the driver solely perceives the passenger as another $\$ 100 \mathrm{COP}$ commission.

\section{A. Colombian Government's Strategic Planning towards the Improvement of Public Transportation and Supply Management in Intermediate Cities}

Another challenge for the Colombian Government in 2015 will be reorganizing public transportation operation and establishing traffic management measures in the main intermediate cities in order to prioritize public transportation in specific corridors, unify tariff collection, and re-structure routes [5].

Then, the concern for public policy building is to structure an inclusive urban project that promotes accessibility for people and goods in order to reach their destinations as a priority objective in public transportation integration, and in the future, the incorporation of intercity transportation systems involving monorails and tramlines [6].

The implementation of a bus-based mass transit service-BRT in Colombia goes back to 2000 when TransMilenio started operating in the Colombian capital city; afterwards, this model was applied in the rest of the main cities of the country [7]. However, when copied, adjustments were not considered, especially in terms of tariff zones integration strategies, which besides motivating passengers to use public buses, it could help them organize an expenditure plan for traveling purposes. The aftermath is a planning deficiency in the BRT's operation, a reduction in citizens' mobility capability, and a decrease in their access to services and infrastructures [8]. Table I illustrates the current situation of the different BRT systems implemented in the country.

Table I. Current Condition of Brt Systems in en Colombia

\begin{tabular}{|c|l|l|l|}
\hline City & Manger & $\begin{array}{c}\text { Operation } \\
\text { Starting Date }\end{array}$ & \multicolumn{1}{c|}{ Current Situation } \\
\hline Bogotá & Transmilenio & December 2000 & $\begin{array}{l}\text { The BRT is self-supporting; the main problem is not the lack of passenger } \\
\text { flow but its high demand, which has not been satisfactorily covered by the } \\
\text { system. }\end{array}$ \\
\hline Pereira & Megabus & August 2006 & $\begin{array}{l}\text { It is one of the first BRT systems in the country, but it has not been able } \\
\text { to reach break-even point -BEP. The main problem it currently has is the } \\
\text { contract termination with one of its transportation operators. }\end{array}$ \\
\hline Bucaramanga & Metrolínea & Mecember 2009 & $\begin{array}{l}\text { This BRT system has the greatest coverage in the country since it almost } \\
\text { covers 90\% of the city's territory. However, its main problem is related to the } \\
\text { quality of the service it provides. This complaint results in a low passenger } \\
\text { flow. }\end{array}$ \\
\hline Barranquilla & Transmetro & April 2010 & $\begin{array}{l}\text { This not been able to reach BEP. } \\
\text { It has maybe one of the worst systems because since the beginning it had } \\
\text { serious problems with parallelism; additionally, it has fewer buses than } \\
\text { what they actually require. For this reason, it has been the first to receive } \\
\text { government funding. }\end{array}$ \\
\hline Cartagena & Transcaribe & Not operating & $\begin{array}{l}\text { Cartagena's BRT construction started in January, 2006. It has been eight } \\
\text { years and the operation has not started yet. }\end{array}$ \\
\hline
\end{tabular}

Source: Authors. 
Part of the current problems in BRT systems is the parallel operation of the conventional public transportation, known as parallelism, so transportation now combines a decentralized supply and a planned one. The latter is managed by a unique or central agent that provides a low quality service and offers inadequate infrastructure; additionally, the transportation management entities show a lack of regulation policies and authority exercise [9].

The service supplied by different actors is not coordinated; besides this, obsolete buses, inadequate route and operation schemes, and oversupply of certain frequencies characterize the service, thus, reducing passenger flow in BRT systems.

A tariff zone integration strategy could balance user's welfare, travel time and quality, and operation costs in the system. Mohring effect [10] explains that if the bus frequency increases, the passenger's welfare also does since average waiting time reduces. Waiting time then is part of transportation costs, since the more passengers use the service, the lower the cost of existing passengers. Thus, bus frequency increase brings balance between quality of service and operation cost optimization.

\section{Metropolitan Area of Bucaramanga: SCENARIO RECOGNITION}

A clear lack of road infrastructure is hindering fluid communication between the municipalities in the Metropolitan Area of Bucaramanga -MAB. Also, an imbalance between the daily infrastructure demand and the permanent growing demand is evident (Fig. 1). This inequity has become a common problem in the MAB bringing social costs unquantifiable so far.

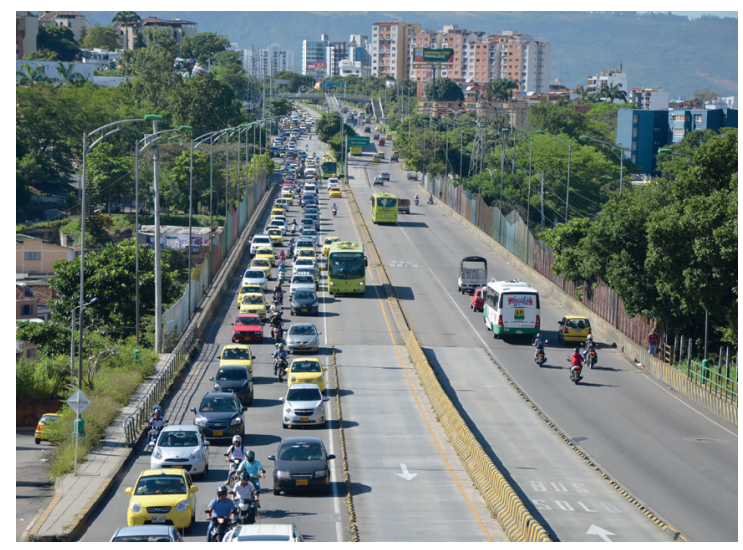

Fig. 1. Current infrastructure deficiency vs multiple public transportation operators. Source: Authors.

Some problems related to road infrastructure and public transportation service in the MAB are listed hereunder:
- A lack of urbanization control in the municipalities of the MAB, i.e., the construction of big buildings or department stores without considering the vehicle fleet increase this generates, hence, augmenting the imbalance between road infrastructure supply and vehicle fleet demand.

- The low coverage of supplementary routes of $\mathrm{BRT}$ in the MAB and the frequency irregularities of the service have forced users to look for alternative ways to transport.

- A low-efficiency use of the BRT exclusive lane.

- Waiting time uncertainty during public transportation journeys fosters private car use and informal transportation systems such as collective taxis and/or motorcycle taxi.

- Aggresive driving styles of BRT drivers between Cañaveral and Molinos stations and on the García Cadena viaduct when looking for passengers in the Antonia Santos stop disturbs traffic in the mixed lane.

It is well known that the coexistence of these two public transportation systems with different tariff structures within the MAB is not time-efficient. The conventional system, still fighting the 'cent war', is opposed to the Government's National Policy regarding the improvement of the Collective Urban Public Transportation -TPCU of passengers [9]. Fig. 2 shows a diagram of the public transportation problems.

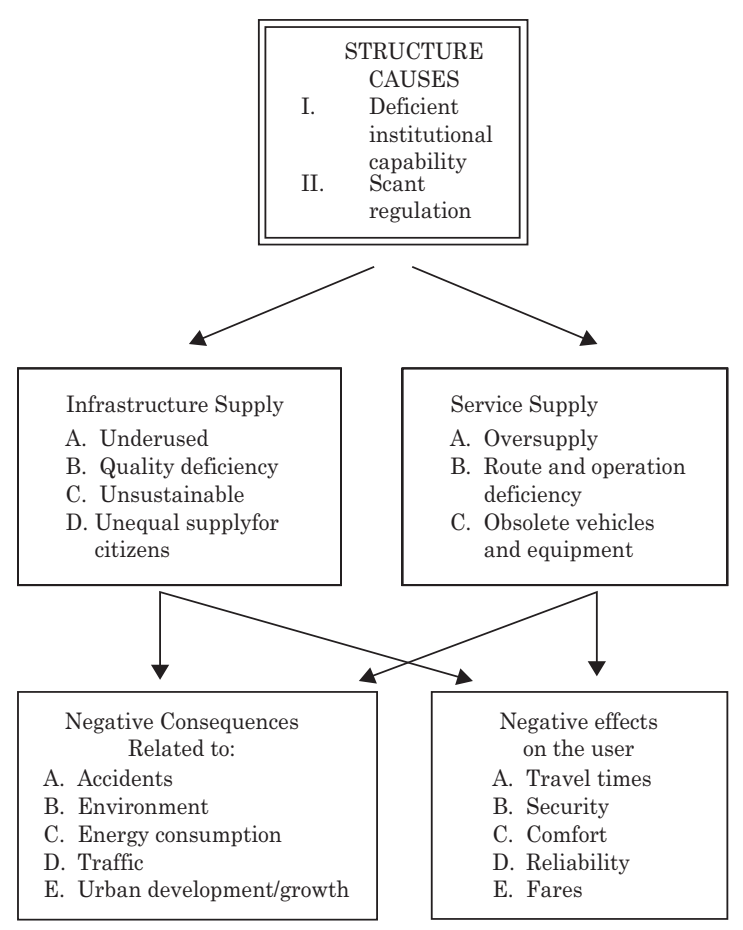

Fig. 2. Problems of the conventional public transportation. Source: Consejo Nacional de Política Económica y Social 3167 de 2002 . Ministerio de Transporte. DNP: DIES-GEINF. 
Furthermore, BRT Metrolínea's deficiencies [11] regarding frequency, coverage, sale and reload points of sale, and service quality have forced users to retort to alternative -sometimes illegal- transportation means like the motorcycle taxi, sharing the cost of a fare in a collective taxi, or the use of private cars as 'pirate taxis', among others. The emergence of this informal transportation in Piedecuesta, Girón, and the Northern area of Bucaramanga, as well as the permanent increase of private cars and motorcycles threat the BRT system in the MAB [12].

Given this situation, the aim is to attract people to use the BRT in the MAB. For this, several strategies are to be set forth, for instance, the construction and improvement of infrastructure -bus stops, roads, stations, parking zones, etc.-, setting more point of sales to buy and reload smart cards, the implementation of real-time information mechanisms, the increment of supplementary routes coverage, a frequency increase, the implementation of an internal audit, the improvement of customer service, and the update of the current tariff model [13].

For the service provider, the tariff has a basic interest since the revenue is the difference between the operation costs and the total income. For the passenger, the tariff is important, especially for lower and middle classes, because it affects their family monthly budget as it is a crucial expenditure in order to commute to work, mainly. More importantly even, is the minimum level of the service covered by the fare. The option of arriving to the destination without any uncertainty, without waiting for a long time, or without broken vehicles, should be minimum requirements for the public transportation system. For their part, authorities as passengers' representatives ought to analyze costs to determine whether the tariff and the service offered are compatible.

Considering the elasticity of demand [14] -when varying the tariff, the quantity of travels does not vary-, the tariff is determined by (1):

$$
\text { Tarifa }=\frac{c(Q)+u}{N}
$$

Where:

$c(Q)$; is the cost that should depend on the service quality. Nonetheless, the tariff is equal

for any service.

$u$; is the expected income the operator intends to achieve for every transported passenger. The income is normally adopted as a percentage of the cost or invested capital in order to provide the service.
$N$; is number of passengers (pax) transported. This datum makes the travel fare can change according to the company and city.

The operator is interested in shaping every cost the TPCU exploitation process involves in order to estimate the total cost for the service provision at different production levels, since based on these values, the minimum income the service or product will obtain can be established [15].

Total costs can be established by the addition of fixed and variable costs through (2):

$$
C T=C F+N * C V
$$

Where:

$C T$ : Total Cost

$C F$ : Fixed Cost

$C V$ : Variable cost per produced unit

$N$ : Units produced (in this case number of passengers)

According to the Colombian Ministry of Transport's Resolution No. 0004350 of December 31,1998 [16], the following cost structure is established:

1. Variable Costs: Fuel, lubricants, tires, vehicle maintenance, salaries and social benefits.

2. Fixed Costs: Parking, management and use fees, taxes, and insurance.

3. Capital Costs: Profitability and capital payback.

Also, for the BRT Metrolínea system, the cost for the fare collection technology and its distribution need to be included in the budget because this is an operation and management monthly expense. The duty is performed by a company in charge of collecting Metrolínea's money. In this case, the company is TISA S.A. and earns a commission per sold ticket. The commission is a $13.5 \%$ of the ticket's value [17]. In 2014, the ticket was $\$ 1700$ COP (US\$ 0.71), so TISA S.A. received $\$ 229.5$ COP (US\$ 0.095) per ticket.

Now, as it is shown in the study hired by the MAB (2011) [18], the main income source for the BRT Metrolínea is the daily sale of tickets at the established technical rate. This rate is quantified as the relation of the total BRT's expenditures over the total number of validated tickets - of passengers effectively transported- of the system. The licensee's bid tariffs are adjusted every six months according to Metrolínea's operative cost increase. Particularly, tariff update per kilometer for every type of vehicle is based on the operation cost increase [17]. This is performed using (3):

$$
\operatorname{Taju}_{j, i}=T_{j, i-1} \cdot\left\{1+\left[\left(0.67 \cdot \operatorname{VIPC}_{\mathrm{i}-1-1}\right)+\left(0.13 \cdot \operatorname{VIPP}_{i-1}\right)+\left(0.2 \cdot V C C_{j, i-1}\right)\right]\right\}
$$


Where:

$\operatorname{Taj}_{j, i}:$ Licensee's adjusted tariff for the period

$T_{j, i-1}$ : Licensee's tariff for the period immediately preceding

$V I P C_{i-1}$ : Consumer Price Index variation for the period immediately preceding -certified by the National Administrative Department of Statistics (DANE)

$V_{I P P_{i-1}}$ : Producer Price Index variation for the period immediately preceding -certified by DANE

$V C C_{j, i-1}$ : Licensee's Fuel Cost Index variation

Regarding the licensee's revenue during the time the license is in force, the value is determined by the kilometers traveled, the type of buses of the fleet, and the operation service orders emitted by Metrolínea S.A. effectively executed by each of the buses operating for Metrolínea subjected to the income level obtained through the journeys which constitute the payment. The licensee's total income corresponds to the total amount of income received during all the buses' trajectories and the adjustment of the Service Level factor.

As it can be seen, there is an inconsistency between the tariff's value per kilometer that the system pays to its operators and the flat rate the user pays to the system. The flat rate is not linked to the traveled distance or the type of bus used.

It can be said that for the public transportation in the $\mathrm{MAB}$, three types of tariff structures are used:

1. Flat Rate for the users traveling in bus, whether it is from the conventional or the BRT system; $\tau_{i j}=\tau_{p}$ where $\tau_{i j}$ : is the origin-destination fare and $\tau_{p}$ : is the flat rate.

2. Tariff per Kilometer is for the licensee operator of Metrolínea $\tau_{i j}=\tau_{u} \cdot x_{i j}$, where $\tau_{i j}$ is the origindestination fare, $\tau_{u}$ : is the unit fare, and $x_{i j}$ : is the trajectory traveled between origin and destination.

3. Mixed Tariff, i.e., access and kilometer paid by taxi users $\tau_{i j}=\tau_{e}+\tau_{u} \cdot x_{i j}$, where $\tau_{\mathrm{ij}}$; is the origin-destination fare, $\tau_{e}$ : is the access fare, $\tau_{\mathrm{u}}$ : is the unit fare and $x_{i j}$ : is the trajectory traveled between origin and destination [19], (Fig. 3).
The parallel use of two public bus systems in the MAB complicates tariff management. The conventional system has a low efficiency; it has low quality, comfort, and security levels, and travel time is not coherent with the distance traveled. Regarding this situation, authorities have had a passive role for a long time, usually due to a lack of human and technical resources. The same fare calculation, in many cases, has based on poor and unreliable information, and through generic methodologies that cannot validate the outcomes. This lack of a basic information record system for the BRT hinders an appropriate tariff management [20].

\section{III.Proposed Tariff Model for Public Transportation in the MaB}

Tariff integration is the key element to dissuade cent war and to start providing a quality and efficient service to people in need of traveling. In this sense, a review of the operator's current remuneration state should be performed in order to establish a payment per passenger effectively transported depending on the trajectory, hence, a tariff structure based on an increasing linear function --distance vs. service demand- should be implemented.

The proposal then refers to a rate bound to the traveled distance, this is, the establishment of tariff zones for the MAB in order to differentiate users traveling short and long distances. Fig. 4 shows the tariff structure proposed in which based on a tariff per kilometer, zones with a flat rate can be established in order to cover the operational costs. In this case, the flat rate $1\left(\tau_{p 1}\right)$ is lower $\left(\tau_{p} 1<\tau_{p} 2<\tau_{p} 3\right)$ than the flat rate of the rest of the areas covered by the transportation system. The idea is that the flat rate 1 reaches the areas with more demand and covers distances of approximately $15 \mathrm{~km}$. Topology also needs to be taken into account.

Considering that passengers are charged a flat rate regardless the distances traveled and operators are paid a tariff per kilometers -inconsistent with the incomes received, an equitable tariff zone is structured.

\section{Flat Rate}

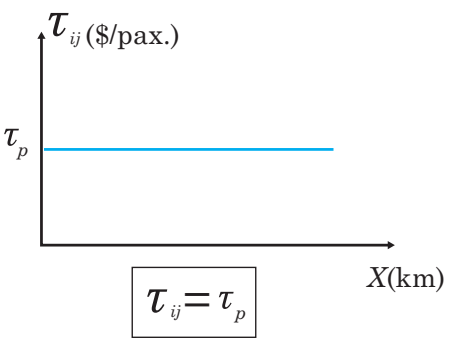

Tariff per Distance (Km)
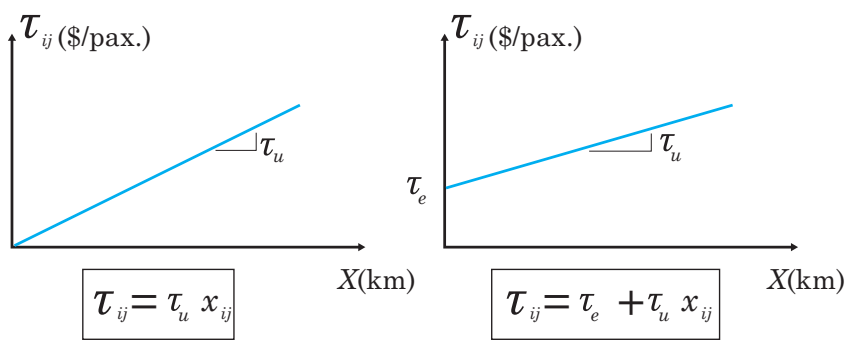

Fig. 3. Tariff structures applied to public transportation in the MAB. Source: Authors. 


\section{TARIFF ZONES STRUCTURE}

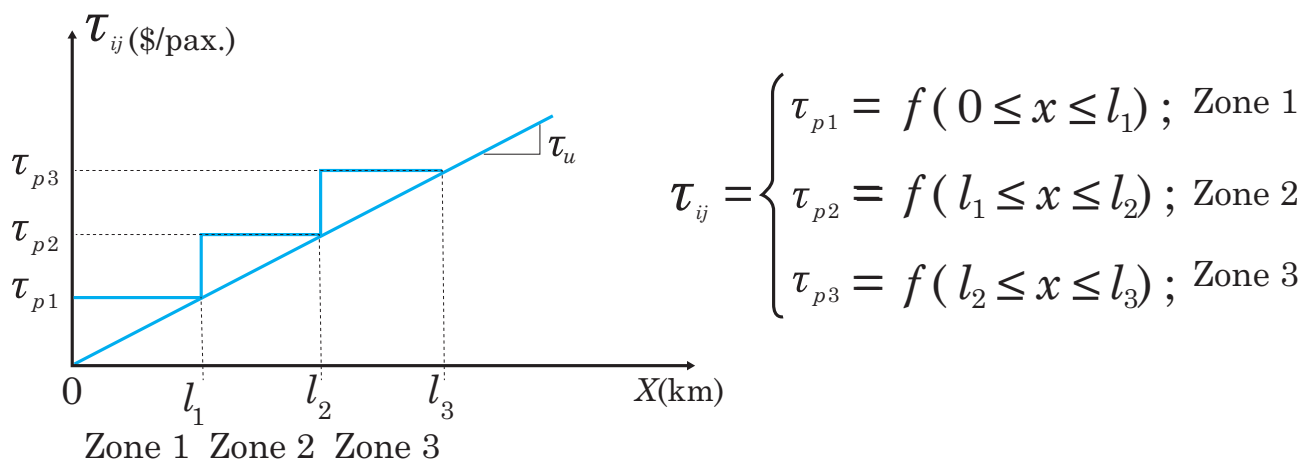

Fig. 4. Tariff strucutre proposed for the public transportation in the MAB. Source: Authors.

Based on the recognition and its ellipse-like topography -having its main axis in the South-North direction-, the tariff zone proposed for the MAB and its neighboring municipalities will have two zones, as shown in Fig. 5 .

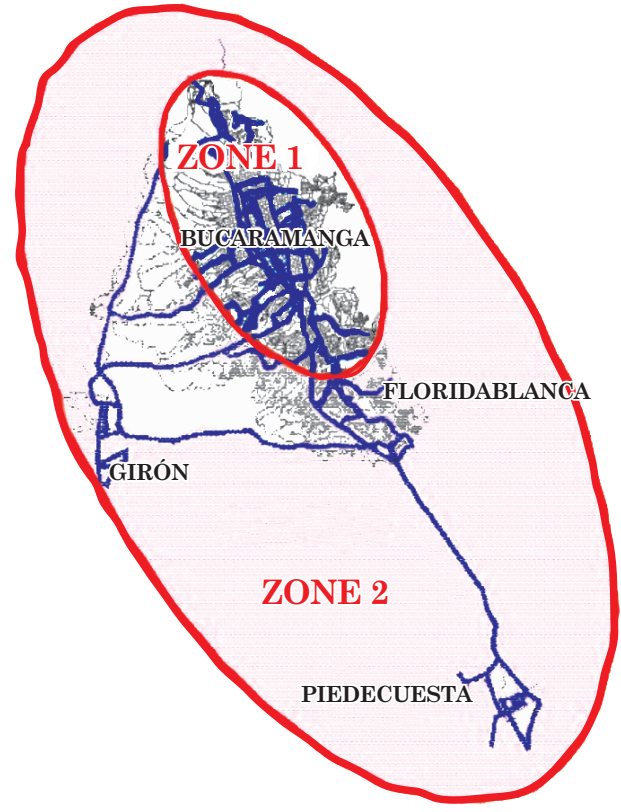

Fig. 5. Proposed tariff zones for public transportation in the MAB. Source: Authors.

The first zone aims to reach most of the neighborhoods in Bucaramanga, for the lower classes mainly, la Joya and Morrorico, and Provenza and some further neighborhoods. Also, some Floridablanca neighborhoods like La Cumbre, El Molino, and a sector of El Bosque, however, it does not cover Cañaveral, Lagos, and the center and southern zones. Approximately, the south-north trajectory would have $13 \mathrm{~km}$ and the west-east trajectory $7 \mathrm{~km}$. This distribution fits a main branch system as the current south-north roads have enough capability to transfer the passenger volume coming from the MA's west and east. The fare for 2015 is $\$ 1850$ COP (US\$ 0.77).

Zone 2 reaches the external part of zone 1 and covers all the MAB; it can even go as far as Lebrija and Ríonegro. Trajectories surpass $30 \mathrm{~km}$ in the southnorth direction and $20 \mathrm{~km}$ in the west-east direction. In this case, the aim is passengers make an optimum use of travels to Bucaramanga's node since the flat rate for this zone would be around $\$ 2050$ COP (US $\$$ 0.85). Also, it is important that complementary buses from each municipality support the main branch by transferring passengers at the big portals in order to be transported by Metrolínea's buses.

In this way, buses traveling in the municipalities and using trunk lanes for more than $50 \mathrm{~km}$ could be avoided, hence, reducing notably operational costs and negative counter-productive events [21]. Of course, passengers traveling from one zone to the other only have to pay for one. At this point, technology is crucial to avoid fraud as it is by the ticket or smart card that it can be known where the travel starts and ends.

Through the application of a zone-tariff strategy, a better tariff integration can be implemented between conventional and mass transportation systems, establishing short travels for the former, and longer for the latter. In this way, $100 \%$ coverage of the system in the MAB could be accomplished, thus, reducing motorcycle taxi service -widely used and accepted in the outskirts; an inefficient control of this informal transportation means all the efforts towards the improvement of the BRT system would be useless.

In order to accomplish the tariff integration conventional public service buses would need to be adjusted using technology; the 'cent war' would also be eliminated through clear operation rules. As consequence, more accessibility and coverage would benefit passengers, as well as better card reload options [22]. 
The trip production and attraction exerted by Bucaramanga over the other MA municipalities support the zonal tariff establishment -as seen in the trip generation model [23], especially at rush hours. As observed in Fig. 6, desired trip lines in all the municipalities allow forecasting that zonal tariff will prevail due to the higher housing density in Bucaramanga and the population growth in the other municipalities.

The desired trip lines for each municipality reinforce the radial mobility patterns from Girón and Piedecuesta to the metropolitan center; in the case of Bucaramanga and Floridablanca, trips seem more distributed within Bucaramanga, which remains as the main attractor of the rest of the public transportation trips in the MAB.

Another important aspect to consider is the relation between the public transportation demand and the daily supply, in other words, it is important to identify the way in which trips are distributed through the transportation corridors. As of an assignment model and several repetitions to measure the network using information from the MAB's origin and destination trip matrix, the most used corridors were preliminary determined for both the conventional and the mass transportation systems [18].

Fig. 7 illustrates that the longitudinal corridors of the Piedecuesta-Bucaramanga, Carreras 15, 21, 27, and 33 have the highest demand; these connect the municipalities with the MA's center. Additionally, according to the MAB's shape, an elongated area in the south-north direction and a more limited space in the west-east direction can be observed due to the presence of the eastern mountain range surrounding the city. For this reason, the main roads, which are few in the south-north direction, act as core trunk lanes from the north of Bucaramanga to the expanding zone outside the plateau: Floridablanca, Piedecuesta, and Girón.
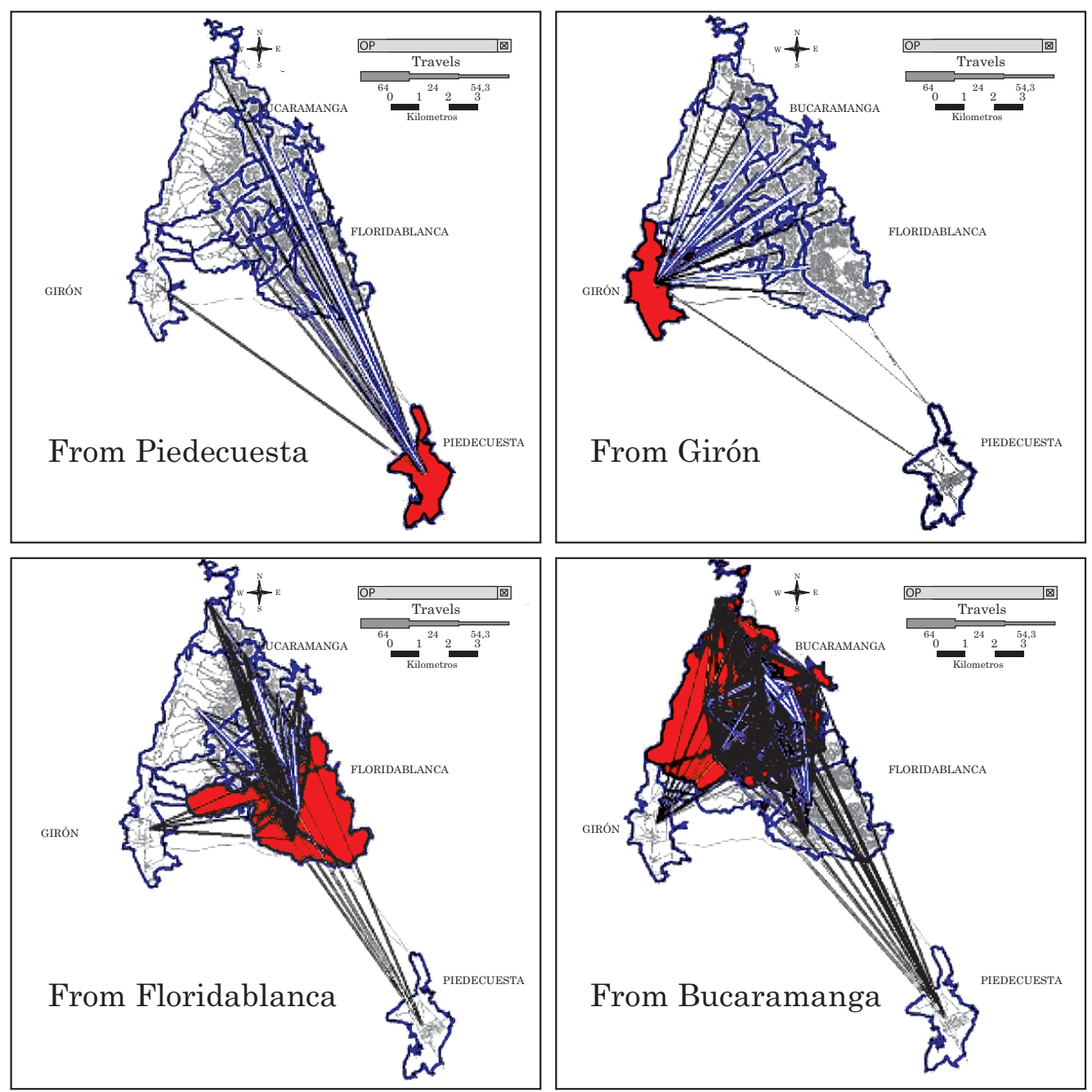

Fig. 6. Desired trip lines from each of the municipalities of the MA. Source: [18] 
In accordance with the studies carried out in [18], the total demand was estimated in 482,789 passengers divided in both systems: $407,797=84.5 \%$ for the conventional system and $74,992=15.5 \%$ for the mass system. This trip allocation implies the improvement of the public transportation regulations in the MAB so as to integrate these two systems, which deliver not only unfair competition but also a low-quality service. For this reason, this proposal should be seriously considered as a future goal for the Integrated Public Transportation System-IPTS.

Moreover, these studies indicate that in that year (2011), in which the BRT's second phase had not started operating yet, 62 lines of the conventional system were operating -licensed to 12 companies with a total fleet of 1,401 units-, traveling a total of $2,077 \mathrm{~km}$-equivalent to the $0.25 \%$ of the total road network in the MAB. A concerning matter is that "the main characteristic of the current system is the overlapping of conventional bus routes and the diversity of destinations. In average, the routes cover $33.5 \mathrm{~km}$ per route; route 38 travels more than $50 \mathrm{~km}$ and it belongs to the Transpiedecuesta Com- pany, as well as routes 56 and 57 -Villa de San Carlos Company-, and the routes traveling less than 15 $\mathrm{km}$ are Unitransa's route 3 -Álvarez-La Joya and TransColombia's route 16 -La Feria" [18]. In 2011, the flat rate charged to users was $\$ 1550$ COP (US\$ 0.62 ), just as for the BRT. Because of this difference in traveled distances, this zonal tariff is proposed for the IPTS.

\section{Conclusions}

By studying the solutions implemented in large cities worldwide like Stockholm, London, Oslo, Trondheim, Berge, and others regarding the application of an integrated tariff in the public transportation system through the use of zonal rates, the possibility of applying this method in the Metropolitan Area of Bucaramanga, Colombia was considered, mainly because it would promote sustainable mobility. This concept refers to the organized transportation that makes optimum use of energy, timing, trajectories, and transportation conditions in order to enjoy today a vital service in the city without threatening that possibility for future generations.

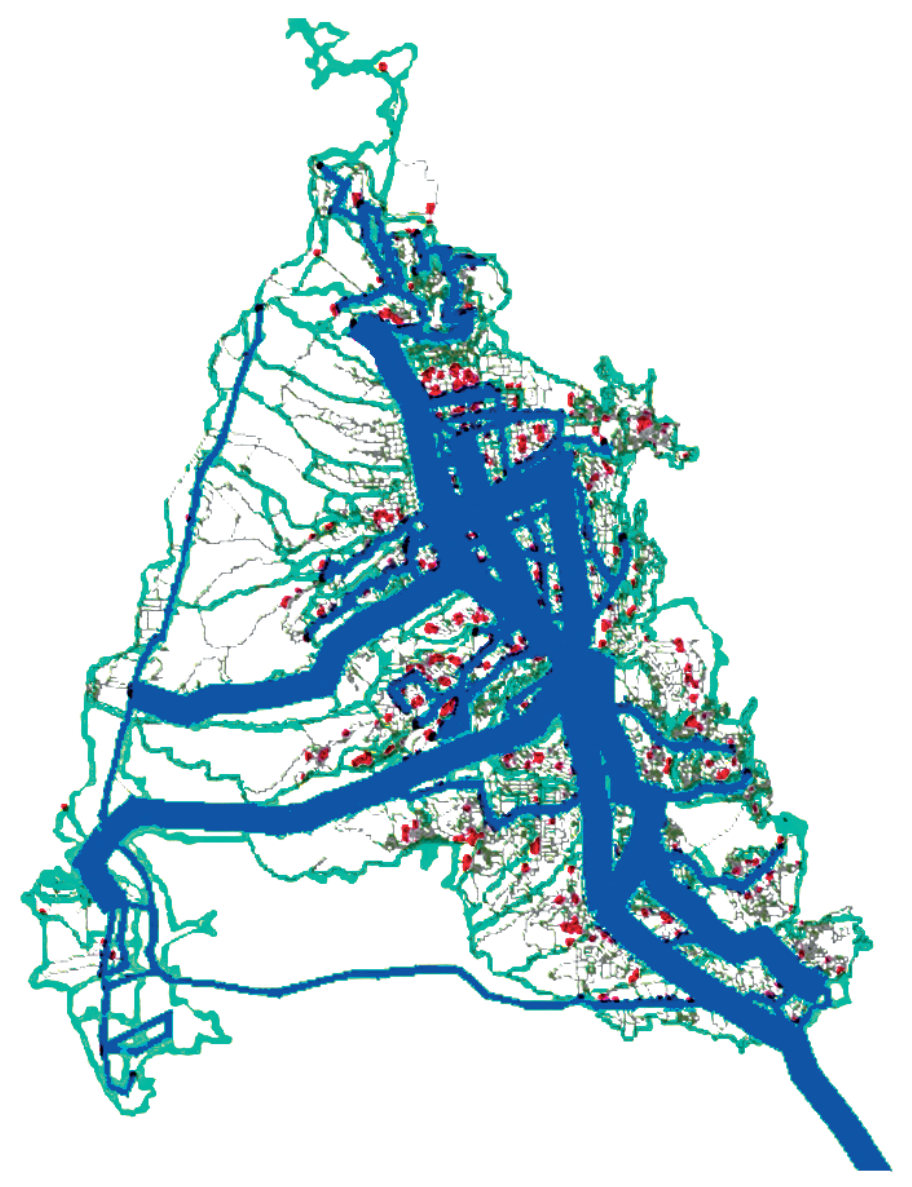

Fig.7. Transport demand through the corridors in the MAB Source: Authors based on [18]. 
For this purpose, actions providing an efficient solution to coverage, quality, frequency, and routes in the MAB's transportation system are required. The solution must be directed towards the implementation of an Integrated Public Transportation System or IPTS, as already proven in many cities of the world. In addition to a better planning of the Area, changes in the urban land use, the establishment of a hierarchy of roads in accordance with their functions and capacities, an improvement in the accessibility, and the priority provision to public transportation routes, IPTS set forth the technical, operative, and tariff integration of the different public transportation modes, and in this way, bring together the BRT system, which would be the main core of the overall system.

At an institutional level, the trend should direct towards the appointment of a Metropolitan Transportation Authority in charge of planning, managing, and making profitable the project so as to improve on a daily basis the MAB's quality of life by reducing travel times between the different municipalities and granting accessibility to everyone. Also, sustainable mobility; daily, weekly, and monthly travel 'packages'; and discount to special groups -students and elderly people- need to be offered by the system. The abovementioned elements are necessary to provide a more equitable service to users who are far from the city center.

Tariff integration is a fundamental aspect to dissuade 'cent war' and provide an efficient public transportation system to all the people in need of traveling. In this sense, a review of the current conditions regarding operator's payment should be carried out to finally establish a payment per effectively transported passenger depending on the distance traveled.

As the municipalities of Bucaramanga and Floridablanca have the most demanded traveling route, it is concluded that a zonal rate should be implemented for these two boroughs.

\section{REFERENCES}

[1] G. Giuliano, J. E. Moore II, and J. Golob, "Integrated Smart-Card Fare System: Results from Field Operational Test," Transp. Res. Rec., vol. 1735, pp. 138-146, 2000. DOI:10.3141/1735-17

[2] G. Hinterwälder, C. T. Zenger, F. Baldimtsi, A. Lysyanskaya, C. Paar, and W. P. Burleson, "Efficient e-cash in practice: NFC-based payments for public transportation systems," Priv. Enhancing Technol., vol. 7981, pp. 4059, 2013. DOI:10.1007/978-3-642-39077-7_3

[3] J. Porter, "The case of Transmilenio in Colombia," $P U$. BLIC WORLD, 2010. [En línea]. Disponible en: http:// www.publicworld.org/files/colombiabrtenglish.pdf.

[4] G. Mendoza, "Análisis del mercado de servicios de transporte público en España," Investig. económicas, vol. 15, no. 2, pp. 229-248, 1991.

[5] J. A. Sanin, Desarrollo del Transporte en Colombia, 1st ed. Bogota: Ministerio de Transporte, 2007, pp. 736-740.
[6] C. Brand and J. Preston, "Which technology for urban public transport?," Proc. ICE - Transp., vol. 156, no. 4, pp. 201-210, 2003. DOI:10.1680/tran.2003.156.4.201

[7] T. Yepes, J. C. Junca, and J. Aguilar, "La integración de los sistemas de transporte urbano en Colombia," $\mathrm{Fe}$ desarrollo Centro de Investigación Economica y Social, 2013. [En línea]. Disponible en: http://www.repository. fedesarrollo.org.co/handle/11445/175.

[8] A. Iracheta, "La necesidad de una Política Pública para el desarrollo de sistemas integrados de trans portes en grandes ciudades Mexicanas," Rev. Invi, vol. 26, no. 71, pp. 133-142, 2011. DOI: 10.4067/s0718. 83582011000100006

[9] Departemento Nacional de Planeación and Ministerio de Transporte, "Politica Para Mejorar el Servicio De Transporte Público Urbano de Pasajeros," Ministerio de Transporte, 2002. [En línea]. Disponible en: https:// colaboracion.dnp.gov.co/CDT/Estudios Econmicos/191. pdf.

[10] P. van Reeven, "Subsidisation of Urban Public Transport and the Mohring Effect," J. Transp. Econ. Policy, vol. 42, no. 2, pp. 349-359, 2008.

[11] Vanguardia, "Sistemas de transporte masivo, un modelo en aprietos.," Vanguardia, 2013. [En línea]. Disponible en: http://www.vanguardia.com/actualidad/ colombia/226683-sistemas-de-transporte-masivo-unmodelo-en-aprietos.

[12] P. Wilkinson, "Incorporating informal operations in public transport system transformation: the case of Cape Town, South Africa," Brazilian J. Urban Manag., vol. 2, no. 1, pp. 85-95, 2010.

[13] C. F. Pardo, "Los cambios en los sistemas integrados de transportes masivos en las principales ciudades de America Latina," Publicacion de las Naciones Unidas, 2009. [En línea]. Disponible en: http://www10.iadb.org/ intal/intalcdi/pe/2009/04142.pdf.

[14] G. Mendoza, J. Campos, and G. Nombela, Economía del transporte, 1st ed. Barcelona, 2003, pp. 140-145.

[15] F. Ventura, Els Comptes del Transport de Viatgers a la Regio Metropolitana de Barcelona, 1st ed. Barcelona: Universidad Politecnica de Cataluña, 2000, pp. 95-136.

[16] Ministerio de trasnporte, "Documentos," 1998. [En línea]. Disponible en: https://www.mintransporte.gov.co/ documentos.php?id=14\&colorder $=$ fecha\&order $=$ ASC . [Consultado el 19-abr-2014].

[17] Departamento Nacional de Planeación, "Informe Final de la Evaluación expost de la Fase I del SITM del Área Metropolitana de Bucaramanga -AMB- Metrolínea", SIGMA Gestión de Proyectos SAS, Bogotá, 2012

[18] Universidad Industrial de Santander, "Documento Técnico de Consultoría para el Análisis de la Situación Actual y Futura del Transporte Colectivo Complementario del área Metropolitana de Bucaramanga”, Bucaramanga, 2011

[19] M. H. Salas Rondón, "Análisis de estrategias tarifarias para la gestión de la movilidad en carreteras metropolitanas”, Universidad Politécnica de Cataluña, 2008.

[20] Alcaldía Mayor de Bogotá and Secretaría de Tránsito y Transporte, Manual de Planeación y Diseño para la Administración del Tránsito y el Transporte, 2nd ed. Bogota: Editorial Escuela Colombiana de Ingeniería, 2005, pp. 2-6.

[21] P. Busquin, External Costs. Belgium: European Communities, 2003, pp. 1-28.

[22] R. M. Lifschitz, "Sistema de transporte urbano de pasajeros de la ciudad de Rosario, Argentina," Urbano, vol. 6, no. 7, pp. 38-44, 2003.

[23] J. de D. Ortúzar and L. G. Willumsen, Modelos de Transporte, 1st ed. Santander: Ediciones de la Universidad de Cantabria, 2008, pp. 197-203. 